\title{
Nitrogen excretion by the surf zone bivalves Donax serra and $D$. sordidus
}

\author{
A. C. Cockcroft \\ Zoology Department and Institute for Coastal Research, University of Port Elizabeth, PO Box 1600, Port Elizabeth 6000 , \\ South Africa
}

\begin{abstract}
Nitrogen excretion by 2 surf zone bivalves, Donax serra and $D$. sordidus, was determined under laboratory and field conditions. Comparison of the forms of nitrogen excreted revealed only slight differences between species, with ammonia and amino acids constituting 70 to $78 \%$ and 21 to $30 \%$ of total dissolved nitrogen (TDN) respectively. During exposure at low tide, ammonia accumulated in $D$. serra mantle cavity fluid at 1 to $10 \%$ of the immersed excretion rates. On re-immersion, an initial uptake of ammonia was recorded with subsequent recovery to peak excretion rates within $2 \mathrm{~h}$. Mass significantly influenced rate of ammonia excretion in both species. The effect of temperature on ammonia excretion rates is reflected in $\mathrm{Q}_{10}$ values of 2.2 (D. serra) and 2.3 (D. sordidus) for starved sand-mussels over the temperature range 15 to $25^{\circ} \mathrm{C}$. Mass-adjusted mean ammonia excretion rates of fed sandmussels were significantly higher than 'starved' excretion rates in both species. $D$. serra and $D$. sordidus recycle a total of $307 \mathrm{~g} \mathrm{~N}$ per m strip of surf zone per year which constitutes $2.3 \%$ of total phytoplankton nitrogen requirements in the surf zone.
\end{abstract}

\section{INTRODUCTION}

Bivalves of the genus Donax are widespread on tropical and temperate exposed beaches (Ansell 1983). Donax serra Röding, the largest species in this genus, occurs on the west and south coasts of southern Africa (Kilburn \& Rippey 1982) and constitutes the largest proportion $(>90 \%)$ of total macrofaunal biomass on beaches in the southeast (McLachlan et al. 1981). Here $D$. serra undergo a semilunar migration pattern with the bulk of the population occupying a position just above the mean tide level during spring tides and lower down the shore during neaps (McLachlan et al. 1979). The smaller and less abundant D. sordidus Hanley undergo marked tidal migrations with the population centre of gravity showing a significant correlation with the position of the swash line (McLachlan et al. 1979).

The abundance of these bivalves indicates their importance not only in surf zone food chains (McLachlan et al. 1980) but also in their regeneration of nutrients. Bivalve populations have been shown to be important in nutrient regeneration in various ecosystems including estuaries (Kuenzler 1961, Jordan \& Valiela 1982), the Baltic Sea (Kautsky \& Wallentinus 1980 , Kautskty \& Evans 1987) and beaches (Lewin et al. 1979, Prosch \& McLachlan 1984).
This study investigates the forms of nitrogen excreted by Donax serra and $D$. sordidus, the effects of body size, temperature, feeding and exposure to air (tidal state) on excretion rates, and the contribution of recycled nitrogen to total phytoplankton nitrogen requirements in a high energy surf zone ecosystem.

\section{MATERIALS AND METHODS}

Mussels for laboratory and field experiments were collected from Sundays River beach situated on the northern shore of Algoa Bay $\left(25^{\circ} 40^{\prime} \mathrm{E} ; 34^{\circ} 00^{\prime} \mathrm{S}\right)$, South Africa, during 1986 and 1987 . Field experiments were conducted to determine the nitrogen excretion rates of Donax serra at various stages of the tidal cycle. During these field experiments the state of tide was monitored and the duration of $D$. serra inundation and exposure to air recorded. Surf and intertidal sand temperatures and the position of the groundwater table were also noted throughout the course of the experiments.

Ten adult Donax serra ( 40 to $>60 \mathrm{~mm}$ total length) were carefully removed from the sediment at measured time intervals from first exposure during ebb tide. Mantle cavity fluid expelled on contraction of the foot into the shell was collected in a glass container. Total shell length of each individual was measured, the $\mathrm{pH}$ and 
volume of the mantle cavity fluid recorded, and the samples frozen for later analysis. Mantle cavity fluid was filtered $(0.45 \mathrm{um})$ before chemical analysis.

To determine the effect of re-immersion on excretion rates, sand-mussels were removed from the intertidal after various times of aerial exposure and individually placed into $500 \mathrm{ml}$ experimental containers holding 250 to $300 \mathrm{ml}$ filtered $(0.45 \mu \mathrm{m})$ seawater. Water samples, which were frozen for later analysis, were removed at $0.5 \mathrm{~h}$ intervals. Fresh filtered seawater was used for each $0.5 \mathrm{~h}$ incubation. To determine the excretion rates of sand-mussels during complete immersion, specimens were removed from the surf around high tide and a similar experimental procedure followed. Excretion rates during late ebb tide, when the number and duration of swashes covering the Donax zone decreased, were determined by removing specimens from the intertidal at $0.5 \mathrm{~h}$ intervals and following the above experimental procedure. The $0.5 \mathrm{~h}$ incubation times of the experiments were reduced to $0.25 \mathrm{~h}$ as swash coverage decreased.

Due to lower abundance and the lack of clear periods of aerial exposure/inundation in the swash zone, the excretion rates of Donax sordidus were only determined during inundation.

To evaluate the effects of starvation on excretion rates, Donax serra were removed from the intertidal after 4 to $6 \mathrm{~h}$ aerial exposure and placed in a $60 \mathrm{l}$ plastic container supplied with sand, filtered seawater $(4 \mu \mathrm{m})$ and aeration. After $8 \mathrm{~h}$ the water was removed and the sand-mussels exposed to air for a further $6 \mathrm{~h}$ before being individually introduced into experimental containers. This procedure ensured that the $D$. serra were without food for 18 to $20 \mathrm{~h}$ before experimentation. $D$. sordidus were starved for $18 \mathrm{~h}$ in a $60 \mathrm{l}$ container supplied with filtered seawater $(4 \mu \mathrm{m})$ before experimentation. Excretion rates of fed sand-mussels of both species were determined on individuals removed from the surf zone at high tide when visible phytoplankton accumulations were present. The field experiments on fed individuals were conducted at 15,20 and 25 $\left( \pm 1^{\circ} \mathrm{C}\right.$ ) while laboratory experiments on starved individuals of both species were conducted at 15,20 and 25 $\left( \pm 0.5^{\circ} \mathrm{C}\right)$. Experiments lasted for $4 \mathrm{~h}$ with water samples $(15 \mathrm{ml})$ removed every hour and frozen for later analysis. Dry mass was calculated from McLachlan (1979) and McLachlan \& Hanekom (1979). Water samples were analysed for ammonia, nitrate, nitrite urea, amino acids and total dissolved nitrogen (TDN) as described in Cockcroft \& McLachlan (1987).

\section{RESULTS}

\section{Donax serra}

Ammonia constituted $70 \%$ and $77 \%$ of total dissolved nitrogen and amino acids $21 \%$ and $30 \%$ of TDN excreted by starved and fed Donax serra respectively (Table 1). Small amounts of urea $(<2 \%$ of TDN) were detected in both instances.

Volume, $\mathrm{pH}$ and ammonia excretion rates in mantle cavity water collected at various times of exposure are summarised in Table 2. Mantle cavity water volume ranged from 0.5 to $5.5 \mathrm{ml}$ ind $^{-1}$ depending on the size range of sand-mussels used in the experiments. No pattern of mantle cavity water volume decrease was noted with time. The $\mathrm{pH}$ of mantle cavity water was always less than that of the surf water and decreased with time of exposure in all experiments. During exposure, mantle cavity $\mathrm{pH}$ ranged from 8.05 to 8.28 with surf water $\mathrm{pH}$ ranging from 8.30 to 8.58 . Ammonia levels in mantle cavity fluid showed an initial increase in concentration but then remained at a relatively constant level which is reflected in the decreasing ammonia excretion rate with time of exposure. No increase in urea concentration was detected in mantle cavity fluid during exposure although an increase in amino acid concentration was found.

The ammonia excretion rates measured during periods of immersion, exposure to air and re-immersion at various states of the tide (Fig. $1 \mathrm{~A}$ to $\mathrm{G}$ ) showed consistent trends despite differences in temperature and season. Excretion rates during complete immersion around high tide remained fairly constant whereas a sharp decrease in excretion rate was found at late ebb

Table 1 Donax serra and $D$. sordidus. Forms of nitrogen excreted as a percentage of total dissolved nitrogen for starved and fed sand-mussels. Mean values given with range in parentheses

\begin{tabular}{|c|c|c|c|c|c|c|}
\hline Species & Diet & Ammonia & Nitrate & Nitrite & Urea & Amino acids \\
\hline \multicolumn{7}{|l|}{ D. serra } \\
\hline & Starved & $70(55-91)$ & $<1$ & - & $<1$ & $30(15-38)$ \\
\hline & Fed & $77(65-96)$ & $<1$ & - & $2(0-4)$ & $21(12-30)$ \\
\hline \multicolumn{7}{|c|}{ D. sordidus } \\
\hline & Starved & $73(62-95)$ & $<1$ & - & $<1$ & $27(16-36)$ \\
\hline & Fed & $78(68-97)$ & $<1$ & - & $<1$ & $22(10-35)$ \\
\hline
\end{tabular}


Table 2. Donax serra. Summary of mantle cavity fluid volume, $\mathrm{pH}$ and ammonia excretion rates during exposure to air

\begin{tabular}{|c|c|c|c|c|c|c|c|c|c|}
\hline $\begin{array}{l}\text { Date } \\
\text { Tidal phase }\end{array}$ & $\begin{array}{l}\text { High } \\
\text { water } \\
\text { (h) }\end{array}$ & $\begin{array}{l}\text { Low } \\
\text { water } \\
\text { (h) }\end{array}$ & $\begin{array}{l}\text { Surf } \\
\text { temp. } \\
\left({ }^{\circ} \mathrm{C}\right)\end{array}$ & $\begin{array}{l}\text { Sediment } \\
\text { temp. } \\
\left.f^{\circ} \mathrm{C}\right)\end{array}$ & $\begin{array}{l}\text { Time of } \\
\text { exposure } \\
\text { (h) }\end{array}$ & $\begin{array}{c}\text { Mean mantle } \\
\text { cavity water } \\
\text { vol. }\left(\mathrm{ml} \mathrm{ind}^{-1}\right)\end{array}$ & $\begin{array}{c}\mathrm{pH} \text { mantle } \\
\text { cavity water }\end{array}$ & $\begin{array}{c}\mathrm{pH} \\
\text { seawater }\end{array}$ & $\begin{array}{c}\text { Mean } \mathrm{NH}_{4}^{+} \\
\text {excretion rate } \\
\left.\text { (ug ind. }{ }^{-1} \mathrm{~h}^{-1}\right)\end{array}$ \\
\hline $9 \operatorname{Mar} 1986$ & $03: 21$ & $09: 26$ & 22 & 17 & 0.5 & 3.2 & 8.14 & 8.32 & 3.20 \\
\hline \multirow[t]{4}{*}{ Spring } & & & & & 1.0 & 2.9 & 8.12 & 8.35 & 1.06 \\
\hline & & & & & 2.0 & 3.0 & 8.11 & 8.35 & 0.77 \\
\hline & & & & & 3.0 & 2.6 & 8.11 & 8.43 & 0.31 \\
\hline & & & & & 4.0 & 3.0 & 8.05 & 8.42 & 0.29 \\
\hline 17 Apr 1986 & $08: 00$ & $14: 22$ & 18 & & 1.0 & 3.3 & 8.23 & 8.41 & 2.80 \\
\hline \multirow[t]{3}{*}{ Neap } & & & & & 2.0 & 3.6 & 8.22 & 8.40 & 1.00 \\
\hline & & & & & 3.0 & 2.8 & 8.21 & 8.41 & 0.63 \\
\hline & & & & & 4.0 & 3.0 & 8.21 & 8.41 & 0.61 \\
\hline 27 May 1986 & $05: 51$ & $12: 05$ & 20 & 18 & 2.0 & 2.5 & 8.17 & 8.38 & 4.10 \\
\hline \multirow[t]{3}{*}{ Spring/neap } & & & & & 3.0 & 3.1 & 8.15 & 8.38 & 1.04 \\
\hline & & & & & 4.0 & 3.0 & 8.16 & 8.35 & 1.01 \\
\hline & & & & & 5.0 & 2.5 & 8.14 & 8.33 & 0.68 \\
\hline 6 Aug 1986 & $04: 06$ & $10: 09$ & 15 & 14 & 2.0 & 3.1 & 8.24 & 8.31 & 2.10 \\
\hline \multirow[t]{3}{*}{ Spring } & & & & & 3.0 & 3.0 & 8.22 & 8.32 & 1.40 \\
\hline & & & & & 4.0 & 2.6 & 8.22 & 8.31 & 0.85 \\
\hline & & & & & 5.0 & 2.8 & 8.21 & 8.30 & 0.31 \\
\hline 16 Nov 1986 & $03: 06$ & $09: 08$ & 21 & 18 & 1.0 & 3.2 & 8.24 & 8.52 & 2.25 \\
\hline \multirow[t]{3}{*}{ Spring } & & & & & 2.0 & 3.4 & 8.21 & 8.50 & 2.00 \\
\hline & & & & & 3.0 & 3.1 & 8.22 & 8.50 & 0.88 \\
\hline & & & & & 5.0 & 2.8 & 8.20 & 8.51 & 0.88 \\
\hline 7 Dec 1986 & $08: 12$ & $14: 36$ & 25 & 19 & 1.0 & 4.1 & 8.15 & 8.34 & 1.98 \\
\hline \multirow[t]{3}{*}{ Neap } & & & & & 2.0 & 4.5 & 8.15 & 8.34 & 1.08 \\
\hline & & & & & 3.0 & 3.3 & 8.13 & 8.35 & 0.44 \\
\hline & & & & & 3.5 & 4.0 & 8.13 & 8.34 & 0.38 \\
\hline 19 Mar 1987 & $05: 41$ & $11: 50$ & 19 & 17 & 1.0 & 3.1 & 8.22 & 8.29 & 1.48 \\
\hline \multirow[t]{3}{*}{ Spring/neap } & & & & & 2.0 & 3.0 & 8.22 & 8.30 & 1.40 \\
\hline & & & & & 3.0 & 3.3 & 8.18 & 8.31 & 1.01 \\
\hline & & & & & 4.0 & 2.8 & 8.18 & 8.31 & 0.44 \\
\hline 30 Jul 1987 & $05: 59$ & $11: 59$ & 16 & 15 & 1.0 & 4.3 & 8.29 & 8.54 & 2.56 \\
\hline \multirow[t]{3}{*}{ Spring/neap } & & & & & 2.0 & 4.0 & 8.29 & 8.58 & 1.24 \\
\hline & & & & & 3.0 & 5.2 & 8.28 & 8.50 & 0.98 \\
\hline & & & & & 4.0 & 4.5 & 8.28 & 8.54 & 0.55 \\
\hline 2 Aug 1987 & $07: 56$ & $13: 49$ & 17 & 16 & 1.0 & 5.4 & 8.15 & 8.38 & 5.20 \\
\hline \multirow[t]{3}{*}{ Neap } & & & & & 2.0 & 5.2 & 8.12 & 8.38 & 3.94 \\
\hline & & & & & 3.0 & 4.4 & 8.07 & 8.39 & 3.61 \\
\hline & & & & & 4.0 & 5.3 & 8.02 & 8.38 & 2.02 \\
\hline 3 Aug 1987 & $08: 59$ & $02: 45$ & 15 & 15 & 1.0 & 5.0 & 8.19 & 8.38 & 3.55 \\
\hline \multirow[t]{2}{*}{ Neap } & & & & & 3.0 & 4.7 & 8.15 & 8.38 & 2.56 \\
\hline & & & & & 4.0 & 4.5 & 8.15 & 8.38 & 1.25 \\
\hline
\end{tabular}

tide during decreasing swash events. During exposure ammonia accumulated in the mantle cavity fluid. Excretion rates decreased with exposure time and ranged from 1 to $10 \%$ of immersed excretion rates. On re-immersion, an initial uptake of ammonia was recorded with subsequent recovery to peak immersed excretion rates within 2 h. Donax serra exposed to air for various time periods consistently showed an initial ammonia uptake before complete recovery within $2 \mathrm{~h}$. $D$. serra removed from the surf during decreasing swash events and placed in experimental chambers showed an initial decrease in excretion rate but then recovered to peak levels within $1 \mathrm{~h}$, indicating that physical or chemical stimuli and not an endogenous rhythm was responsible for these responses. A generalised scheme of $D$. serra ammonia excretion over a full tidal cycle is presented in Fig. $1 \mathrm{H}$. By integrating these results over a full tidal cycle, it is apparent that intertidal $D$. serra excrete only $49 \%$ of the ammonia they would have if subtidal. During exposure to air the buried $D$. serra were always 15 to $20 \mathrm{~cm}$ above the groundwater table and no evidence of sand-mussels utilizing groundwater for replacement of mantle cavity fluid was noted. 
A. $\operatorname{NEAP}(17 / 4 / 86)$

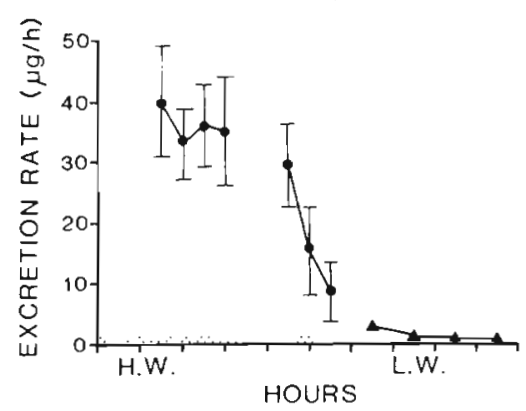

D. SPRING $(16 / 11 / 86)$

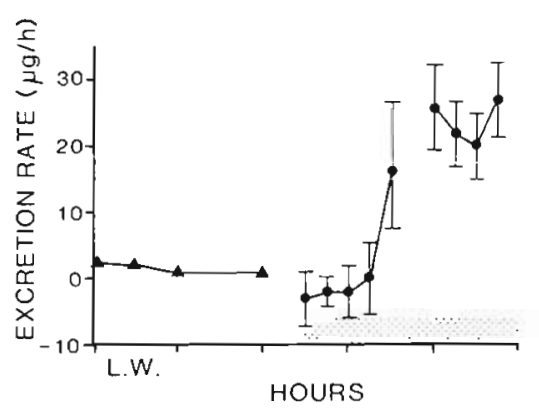

B. SPRING/NEAP $(27 / 5 / 86)$

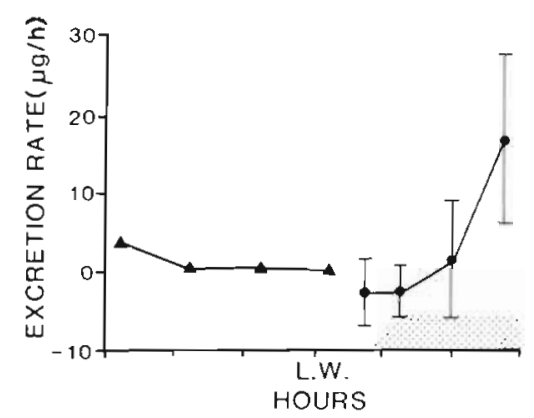

E. NEAP $(7 / 12 / 86)$

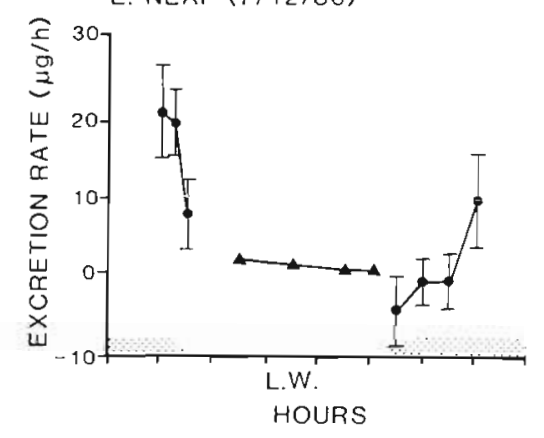

C. SPRING $(6 / 8 / 86)$

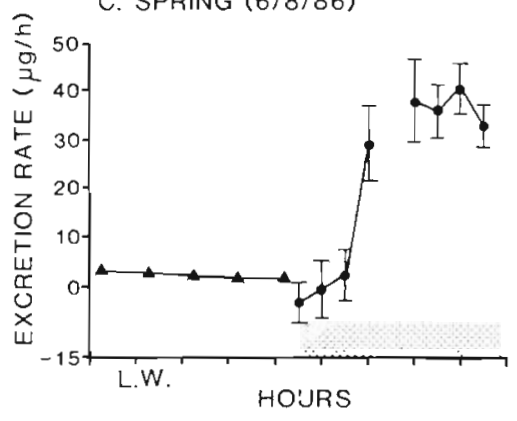

F. SPRING/NEAP $(30 / 7 / 87)$

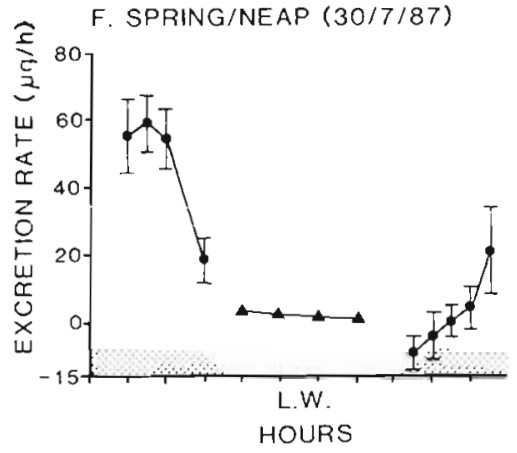

G. NEAP $(2 / 8 / 87)$
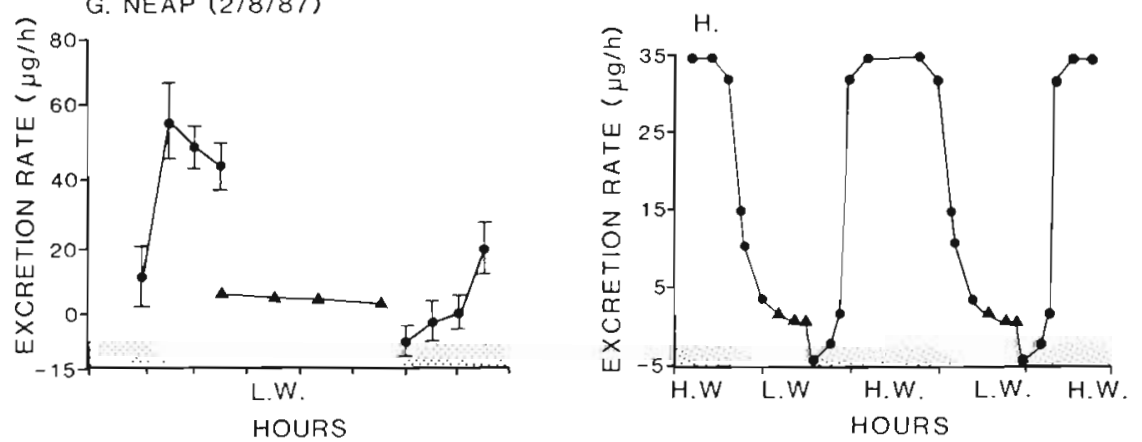

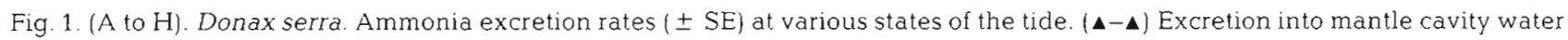
during exposure; $(\bullet-)$ excretion rate while immersed. Negative values $=$ uptake. Shaded areas represent inundation period

The regression equations for starved Donax serra at 3 experimental temperatures (Table 3) showed no significant differences in slope $(p>0.05$, common $b=$ $0.595)$ but significant differences in elevations $(p<0.05)$. Similarly no significant differences in slopes $(p>0.05$, common $b=0.526)$ were obtained in the comparison of regression equations for fed $D$. serra at the experimental temperatures although the intercepts differed significantly $(p<0.05)$. Comparison of regression equations for starved and fed individuals at each experimental temperature indicated no significant differences in slopes $(p>0.05)$ but significant differences in elevations. The effects of temperature on excretion rates are reflected in $Q_{10}$ values. $A Q_{10}$ value of 2.20 was obtained for starved $D$. serra over the experimental temperature range 15 to $25^{\circ} \mathrm{C}$.

Table 4 compares mean ammonia excretion rates ( $\mathrm{ug}$ $\mathrm{NH}_{4} \mathrm{mg}^{-1} \mathrm{~h}^{-1}$ ) of starved and fed sand-mussels at each experimental temperature by analysis of covariance. Mass-adjusted mean ammonia excretion rates for fed Donax serra were significantly higher than rates for starved sand-mussels at 15 and $20^{\circ} \mathrm{C}$ ( $p>0.05$ ) but not at $25^{\circ} \mathrm{C}(\mathrm{p}<0.05)$. The mass-adjusted mean ammonia excretion rate of sand-mussels starved at $15^{\circ} \mathrm{C}$ was significantly lower than at 20 and $25^{\circ} \mathrm{C}(\mathrm{p}>0.05)$, whereas no significant differences were detected between mean adjusted starved rates at 20 and $25^{\circ} \mathrm{C}$ $(p<0.05)$. The mass-adjusted excretion rates of sand- 
Table 3. Donax serra. Regression statistics describing the relationship between ammonia excretion $\left(\mu \mathrm{g} \mathrm{NH} \mathrm{N}_{4}^{+} \mathrm{h}^{-1}\right)$ and dry mass (mg) for starved and fed sand-mussels at 3 experimental temperatures

\begin{tabular}{|clccccc|}
\hline Temp. $\left({ }^{\circ} \mathrm{C}\right)$ & Diet & Log $a( \pm \mathrm{SE})$ & $\mathrm{b}( \pm \mathrm{SE})$ & $\mathrm{r}$ & $\mathrm{n}$ \\
\hline \multirow{2}{*}{15} & Starved & $-0.787( \pm 0.358)$ & $0.597( \pm 0.116)$ & 0.799 & 17 & $<0.01$ \\
& Fed & $-0.428( \pm 0.249)$ & $0.522( \pm 0.087)$ & 0.776 & 26 & $<0.01$ \\
\multirow{2}{*}{20} & Starved & $-0.634( \pm 0.453)$ & $0.607( \pm 0.153)$ & 0.814 & 10 & $<0.01$ \\
& Fed & $-0.322( \pm 0.273)$ & $0.566( \pm 0.096)$ & 0.872 & 13 & $<0.01$ \\
& Starved & $-0.444( \pm 0.565)$ & $0.581( \pm 0.178)$ & 0.719 & 0.012 & 20 \\
& Fed & $-0.094( \pm 0.416)$ & $0.490( \pm 0.140)$ & 0.636 & $<0.01$ \\
\hline
\end{tabular}

Table 4. Donax serra. Results of analysis of covariance comparing mass-adjusted rates of ammonia excretion $\left(\mu \mathrm{g} \mathrm{NH}_{4}-\mathrm{N} \mathrm{mg}^{-1} \mathrm{~h}^{-1}\right)$ for starved and fed sand-mussels at 3 experimental temperatures

\begin{tabular}{|clcccc|}
\hline Temp. $\left({ }^{\circ} \mathrm{C}\right)$ & Diet & $\mathrm{n}$ & $\begin{array}{c}\text { Mean dry mass } \\
(\mathrm{mg})\end{array}$ & $\begin{array}{c}\text { Mean excretion } \\
\text { rate }\end{array}$ & $\begin{array}{c}\text { Adjusted mean } \\
\text { excretion rate }( \pm \mathrm{SE})\end{array}$ \\
\hline \multirow{2}{*}{15} & Starved & 17 & 1478.8 & 0.010 & $0.012 \pm 0.002$ \\
& Fed & 26 & 1066.1 & 0.020 & $0.019 \pm 0.002$ \\
\multirow{2}{*}{20} & Starved & 10 & 1189.0 & 0.018 & $0.020 \pm 0.004$ \\
& Fed & 13 & 1027.4 & 0.032 & $0.031 \pm 0.003$ \\
& Starved & 12 & 1687.3 & 0.018 & $0.026 \pm 0.014$ \\
& Fed & 20 & 1259.8 & 0.043 & $0.039 \pm 0.011$ \\
\hline
\end{tabular}

mussels fed at $25^{\circ} \mathrm{C}$ were significantly higher than at those $15^{\circ} \mathrm{C}(\mathrm{p}>0.05)$, but no significant differences were detected between 15 and $20^{\circ} \mathrm{C}$ or between 25 and $20^{\circ} \mathrm{C}(\mathrm{p}<0.05)$.

\section{Donax sordidus}

Ammonia constituted $73 \%$ and $78 \%$ of TDN excreted by starved and fed Donax sordidus respectively (Table 1). Amino acids constituted $27 \%$ and $22 \%$ of TDN excreted by starved and fed sand-mussels respectively, with insignificant amounts of urea detected in both cases.

The regression equations for starved Donax sordidus at the 3 experimental temperatures (Table 5) showed no significant differences in slopes ( $p>0.05$; common slope $b=0.843$ ) but significant differences in eleva- tions $(p<0.05)$. Similar results were obtained in the comparison of regression equations for fed $D$. sordidus $(p>0.05 ;$ common slope $b=0.77)$. Comparison of regression equations for starved and fed individuals at each experimental temperature indicated no significant differences in slopes $(p>0.05)$ but significant differences in intercepts. The effect of temperature on ammonia excretion rate is reflected in the $Q_{10}$ value of 2.29 obtained for starved $D$. sordidus over the temperature range 15 to $25^{\circ} \mathrm{C}$.

Mass-adjusted mean ammonia excretion rates for fed sand-mussels were significantly higher $(p>0.05)$ than starved rates at all experimental temperatures (Table 6). The adjusted mean excretion rate of Donax sordidus starved at $15^{\circ} \mathrm{C}$ was significantly lower $(p>0.05)$ than the adjusted excretion rate at $25^{\circ} \mathrm{C}$, whereas no significant differences were found between rates at 15 and

Table 5. Donax sordidus. Regression statistics describing the relationship between ammonia excretion $\left(\mu \mathrm{g} \mathrm{NH} \mathrm{H}_{4}^{+} \mathrm{h}^{-1}\right)$ and dry mass (mg) for starved and fed sand-mussels at 3 experimental temperatures

\begin{tabular}{|clccccc|}
\hline Temp. $\left({ }^{\circ} \mathrm{C}\right)$ & Diet & Log $\mathrm{a}( \pm \mathrm{SE})$ & $\mathrm{b}( \pm \mathrm{SE})$ & $\mathrm{r}$ & $\mathrm{n}$ \\
\hline \multirow{2}{*}{15} & Starved & $-1.542( \pm 0.494)$ & $0.901( \pm 0.287)$ & 0.480 & 35 & $<0.01$ \\
& Fed & $-1.214( \pm 0.354)$ & $0.819( \pm 0.198)$ & 0.794 & 12 & $<0.01$ \\
20 & Starved & $-1.434( \pm 0.604)$ & $0.839( \pm 0.342)$ & 0.523 & 18 & $<0.05$ \\
& Fed & $-1.072( \pm 0.274)$ & $0.802( \pm 0.148)$ & 0.854 & 13 & $<0.01$ \\
& Starved & $-1.184( \pm 0.326)$ & $0.788( \pm 0.172)$ & 0.743 & 19 & $<0.01$ \\
& Fed & $-0.855( \pm 0.418)$ & $0.688( \pm 0.243)$ & 0.618 & 15 & $<0.05$ \\
& & & & & & \\
& & &
\end{tabular}


Table 6. Donax sordidus. Results of analysis of covariance comparing mass-adjusted rates of ammonia excretion (ug $\mathrm{NH}_{4}-\mathrm{N}_{\mathrm{mg}}{ }^{-1}$ $\mathrm{h}^{-1}$ ) for starved and fed sand-mussels at 3 experimental temperatures

\begin{tabular}{|cllccc|}
\hline Temp. $\left({ }^{\circ} \mathrm{C}\right)$ & Diet & $\mathrm{n}$ & $\begin{array}{c}\text { Mean dry mass } \\
\text { (mg) }\end{array}$ & $\begin{array}{c}\text { Mean excretion } \\
\text { rate }\end{array}$ & $\begin{array}{c}\text { Adjusted mean } \\
\text { excretion rate }( \pm \text { SE) }\end{array}$ \\
\hline \multirow{2}{*}{15} & Starved & 35 & 52.7 & 0.020 & $0.020 \pm 0.001$ \\
& Fed & 12 & 66.2 & 0.031 & $0.032 \pm 0.003$ \\
& Starved & 18 & 62.6 & 0.022 & $0.021 \pm 0.003$ \\
& Fed & 13 & 82.3 & 0.040 & $0.040 \pm 0.003$ \\
& Starved & 19 & 83.4 & 0.027 & $0.029 \pm 0.003$ \\
& Fed & 15 & 55.3 & 0.044 & $0.042 \pm 0.004$ \\
\hline
\end{tabular}

$20^{\circ} \mathrm{C}$ or 20 and $25^{\circ} \mathrm{C}(\mathrm{p}<0.05)$. Similar results were obtained when comparing the mass-adjusted ammonia excretion rates of fed individuals.

\section{Comparison of Donax serra and $D$. sordidus}

Comparison of the regression equations for starved Donax serra and $D$. sordidus showed no significant differences in slopes $(p>0.05)$ but significant differences in elevations $(p<0.05)$. Similar results were obtained in the comparison of regression equations for fed $D$. serra and $D$. sordidus. Although the intercepts of the regression equations describing the effect of mass on excretion rate of $D$. sordidus were significantly lower than those of $D$. serra, the mean mass-specific excretion rates ( $\mu \mathrm{g} \mathrm{NH}_{4}-\mathrm{N} \mathrm{mg}{ }^{-1} \mathrm{~h}^{-1}$ ) of starved $D$. sordidus were significantly higher (Student's t-test, $\mathrm{p}>0.05$ ) than those of starved $D$. serra at 15 and $25^{\circ} \mathrm{C}$ but not at $20^{\circ} \mathrm{C}$. The mean mass-specific excretion rates of fed $D$. sordidus were only significantly higher than those of $D$. serra at $15^{\circ} \mathrm{C}$. The large mass difference between the species, and the fact that excretion rates of $D$. serra used in the above comparisons are those for the period of immersion only, did not allow a meaningful comparison of mass-adjusted mean excretion rates. Comparison of the amount of ammonia excreted by a $50 \mathrm{mg}$ (dry mass) sand-mussel of each species over a full tidal cycle using the regression equations in Tables 3 and 5 indicated that sand-mussels of equal mass excreted comparable amounts of ammonia over a tidal cycle despite the periods of exposure experienced by the intertidal $D$. serra. If the same procedure is used for a $1000 \mathrm{mg}$ sandmussel (hypothetical in the case of $D$. sordidus), D. serra would excrete considerably less $\mathrm{NH}_{4}$ per tidal cycle than D. sordidus

\section{DISCUSSION}

During exposure to air at low tide Donax serra remains buried 20 to $35 \mathrm{~cm}$ below the sediment surface with siphons retracted, valves closed and the foot extending downwards into the sand. Despite the many other studies on this species on Eastern Cape beaches (Dye 1979, McLachlan \& Hanekom 1979, Ansell \& McLachlan 1980, Ansell 1981, McLachlan \& Young 1982), no information on the metabolism of these animals during exposure is available. Many bivalve species have been shown to withstand periods of shell closure and the resultant lack of oxygen by utilization of anaerobic metabolism. The switch from aerobic to anaerobic respiration in bivalves normally occurs when the oxygen tension of the mantle cavity fluid falls to low levels after valve closure (Akberali \& Trueman 1985). Measurements of the oxygen in extrapallial fluid of the clam Mercenaria (Crenshaw 1972) revealed that it became completely anaerobic within $25 \mathrm{~min}$ of shell closure.

In bivalve molluscs some tissues may be adapted to function anaerobically while others, which are near sites of gas exchange, may be primarily aerobic (Booth. \& Mangum 1978). Some epifaunal bivalve species have been shown to utilize the oxygen diffusing into the mantle cavity fluid through the shell gape during periods of exposure to air (Lent 1968, Moon \& Pritchard 1970, Coleman \& Trueman 1971, Boyden 1972a, b, Bayne et al. 1976a, Widdows et al. 1979) while infaunal species have not been reported to utilize atmospheric oxygen at such times (Boyden 1972a). Although no direct evidence of anaerobic metabolism is available for $D$. serra, the fact that these animals are buried in sediment surrounded by reduced $\mathrm{pO}_{2}$ (although not anaerobic) and that the shell valves are tightly closed for up to $8 \mathrm{~h}$ indicate that this species is likely to operate anaerobically during exposure.

During exposure Donax serra mantle cavity fluid volume remains relatively constant while $\mathrm{pH}$ decreases with exposure time. The accumulation of end products of aerobic metabolism which are usually alanine and succinate (Stokes \& Awapara 1968, Hammen 1969, De Zwaan \& Zandee 1972, De Zwaan \& van Marrewijk 1973), and the increase in $\mathrm{CO}_{2}$ levels, are considered the cause of the $\mathrm{pH}$ decrease in mantle cavity or extra- 
pallial fluid found in some bivalve species during valve closure (Crenshaw 1972, Wijsman 1975, Abkerali \& Trueman 1985).

The accumulation of ammonia in the mantle cavity of Donax serra during exposure occurs at 1 to $10 \%$ of the rate of ammonia excretion during immersion. Similar results were obtained for Mytilus californianus (Bayne et al. 1976a) which accumulated ammonia in mantle cavity fluid at $5 \%$ of immersed excretion rates. No accumulation of ammonia during exposure at low tide was found in Geukensia demissa (Jordan \& Valiela 1982). The difference between exposed and immersed ammonia excretion rates may be due to an increase in glycolysis relative to protein degradation (Bayne et al. $1976 \mathrm{~b})$ or the conversion of ammonia to less toxic end products via a variety of metabolic sequences. The conversion of ammonia to urea was suggested as a possible pathway for the detoxification of ammonia during exposure (Andrews \& Reid 1972) while the fixing of ammonia into alanine (using alanine dehydrogenase) was proposed by De Zwaan \& van Marrewijk (1973) for the same purpose. No increase in urea concentration was noted in $D$. serra mantle cavity fluid during exposure although accumulation may have occurred in the tissues and blood. An increased production of amino nitrogen has been proposed as a mechanism for the detoxification of ammonia under certain circumstances (Bayne et al. 1976b) and the increase in amino acid concentration found in $D$. serra mantle cavity fluid during exposure may serve this purpose. Hammen (1968) suggested that the large concentration difference between tissue and medium amino acid concentration in bivalves caused a leakage of amino acids across the body membranes. Lange $(1970,1972)$ suggested that the loss of amino acids may be a process of active excretion since certain amino acids may be formed as end products of energy metabolism.

The uptake of ammonia during the initial period of immersion after exposure in Donax serra may possibly be due to increased amino acid synthesis to replace lost amino acids. Hammen (1968) suggested that bivalves have very active amino transferase enzymes in order to replace amino acid loss. He recognised that for such replacement to occur, transamination must be coupled with a fixing of ammonia, which is traditionally viewed as the role of the enzyme glutamate dehydrogenase (GDH). Widdows \& Shick (1985) recorded no overshoot in ammonia excretion of Mytilus edulis during recovery after $5 \mathrm{~h}$ exposure to air, rather a conservation or fixation of ammonia at a time of year (winter) when the rate of ammonia excretion was at a seasonal minimum. Experiments on this species in summer (Widdows in Widdows \& Shick 1985) showed a distinct overshoot in ammonia excretion after re-immersion. De Vooys \& De
Zwaan (1978) reported a similar overshoot in ammonia excretion by Mytilus edulis which was proportional to exposure time.

The decrease in ammonia excretion rates in Donax serra exposed to decreasing swash cover is considered purely a response to environmental conditions rather than part of an endogenous rhythm of excretion. Individuals removed during late ebb tide and re-immersed showed a rapid recovery of excretion rate to immersed levels after an initial decrease. Hodgson \& Fielden (1984) identified 2 ciliated sensory receptor types on the siphon and mantle cavity edge in $D$. serra and 3 types in D. sordidus. Estimates of abundance show that the receptors are most numerous on the tips of the siphon tentacles and they suggested that these operate as chemoreceptors.

Ammonia constituted 70 to $78 \%$ of TDN and amino acids 21 to $30 \%$ of TDN excreted by these species. Although ammonia is the dominant form of nitrogen excreted in most bivalves, amino acids constitute a considerable portion of total nitrogen excreted (Lum \& Hammen 1964, Hammen 1968, Allen \& Garret 1971, Bayne 1973). The proportions of excreted forms have been demonstrated to change with stress. Bayne (1973) reported increased amino-nitrogen excretion relative to ammonia nitrogen during stress from temperature and starvation in Mytilus edulis. Urea was not an important component of the nitrogen excreted in Donax serra or $D$. sordidus, although small but significant amounts have been recorded in other bivalves (Lum \& Hammen 1964, Allen \& Garret 1971, Bayne 1973).

Body mass significantly affected the excretion rates of both species. In this study no significant differences in regression coefficients ( $b$ in the expression ammonia excretion rate $=$ a.body size $^{\mathrm{b}}$ ) were found between 'starved' and 'fed' experiments or between species. The mean $b$ values for Donax serra $(b=0.561)$ and $D$. sordidus $(b=0.806)$ are similar to those obtained for $D$. vittatus ( $b=0.639$ ) (Ansell \& Sivadas 1973).

The effect of temperature on ammonia excretion rates is reflected in the $Q_{10}$ values of 2.2 (Donax serra) and 2.3 (D. sordidus) for starved sand-mussels over the temperature range 15 to $25^{\circ} \mathrm{C}$. A mean $Q_{10}$ of 2.07 was found for ammonia excretion by $D$. vittatus between 10 and $20^{\circ} \mathrm{C}$ (Ansell \& Sivadas 1973). In both species studied, 'fed' excretion rates were significantly higher than 'starved' excretion rates at all temperatures with one exception (D. serra, $25^{\circ} \mathrm{C}$ ).

Intertidal adult Donax serra exposed for $4 \mathrm{~h}$ excrete $51 \%$ less ammonia than they would have excreted if inundated for the full tidal cycle. Widdows \& Shick (1985) showed a net energy saving and improved scope for growth in intertidally acclimated Mytilus edulis and Cardium edule compared to intermittently fed subtidal individuals. The intertidal habitat and concomitant 
periods of exposure and anaerobic metabolism may mean a significant energy saving for Donax serra and could be a possible reason for the obvious success of this species on the South African south coast. Further work is clearly required on the anaerobic metabolism of this species during exposure and the role of various enzymes (especially GDH) before final conclusions can be drawn.

Having determined the forms of nitrogen excreted and the effects of temperature, feeding, starvation, and tidal state on excretion rates of these species, the contribution of their recycled nitrogen to total phytoplankton requirements can be estimated. Using the biomass values from McLachlan \& Bate (1984), the innundation periods for the major Donax serra zone (Donn et al. 1986) and the excretion rates from this study, $D$. serra is calculated to recycle $185 \mathrm{~g} \mathrm{NH}_{4}-\mathrm{N}$ per meter strip of surf zone per year or $264 \mathrm{~g} \mathrm{~N} \mathrm{~m}^{-1} \mathrm{yr}^{-1}$. Similarly, $D$. sordidus is calculated to recycle $30 \mathrm{~g} \mathrm{NH}_{4}-\mathrm{N} \mathrm{m}^{-1} \mathrm{yr}^{-1}$ or $43 \mathrm{~g} \mathrm{~N}$ $\mathrm{m}^{-1} \mathrm{yr}^{-1}$. These species therefore cycle $307 \mathrm{~g} \mathrm{~N} \mathrm{~m}^{-1} \mathrm{yr}^{-1}$ which constitutes $2.3 \%$ of total phytoplankton nitrogen requirements in the surf zone (Cockcroft 1988).

Although these values are low compared to the amounts of nitrogen recycled by surf zone penaeid prawns (Cockcroft \& McLachlan 1987) and mysids (Crockcroft et al. 1988) (12\% and 10\% total phytoplankton nitrogen requirements, respectively), the time scale of nutrient release may be of importance. The pulse of nutrients entering the surf zone water column ca $2 \mathrm{~h}$ after inundation of the Donax zone may play an important role in the dynamics of phytoplankton nutrient uptake.

Acknowledgements. Mr Deo Winter is acknowledged for the use of his 'Curvefit' and 'Slope' programs and Helen Crosby is thanked for typing the manuscript. Prof. A. McLachlan. is thanked for appraising the typescript. Financial support came from the CSIR, Department of Environmental Affairs and the University of Port Elizabeth

\section{LITERATURE CITED}

Akberali, H. B., Trueman, E. R. (1985). Effects of environmental stress on marine bivalve molluscs. Adv. mar Biol. 22: 101-198

Allen, J. A., Garret, M. R. (1971). The excretion of ammonia and urea by Mya arenaria L. (Mollusca: Bivalvia). Comp. Biochem. Physiol. 39a: 633-642

Andrews, T R., Reıd, R. G. B. (1972). Ornithine cycle and uricolic enzymes in four bivalve molluscs. Comp. Biuchem. Physiol. 42b: 475-491

Ansell, A. D. (1981). Functional morphology and feeding of Donax serra Roding and Donax sordidus Hanley (Bivalvia: Donacidae). J. mollusc. Stud. 47: 59-72

Ansell, A. D. (1983). The biology of the genus Donax. In: McLachlan, A. Erasmus, T. (ed.) Sandy beaches as ecosyslems. Junk Publishers, The Hague, p. 607-635

Ansell, A. D. McLachlan, A. (1980). Upper temperature tolerances of three molluscs from South African sandy beaches. J. exp. mar. Biol. Ecol. 48: 243-251

Ansell, A. D., Sivadas, P. (1973). Some aspects of temperature and starvation on the bivalve Donax vittatus (da Costa) in experimental laboratory populations. J. exp. mar Biol. Ecol. 13: 229-262

Bayne, B. L. (1973). Physiological changes in Mytilus edulis L. induced by temperature and nutritive stress. J. mar. biol. Ass. U.K. 53: 39-58

Bayne, B. L., Bayne, C. J., Carefoot, T C., Thompson, R. J. (1976a). The physiological ecology of Mytilus californianus Conrad. 2. Adaptions to low oxygen tension and air exposure. Oecologia (Berl.) 22: 229-250

Bayne, B. L., Widdows, J., Thompson, R. J. (1976b). Physiology II. In: Bayne, B. L. (ed.) Marine mussels. Cambridge University Press, Cambridge, p. 121-206

Booth, C., Mangum, C. P. (1978). Oxygen uptake and transport in the lamellibranch mollusc Modiolus demissus. Physiol. Zool.. 51: 17-32

Boyden, C. R. (1972a). The behaviour, survival and respiration. of the cockles Cerastoderma edule and C. glaucum in air J. mar biol. Ass. U.K. 52: 661-680

Boyden, C. R. (1972b). Aerial respiration of the cockle Ceras toderma edule in relation to temperature. Comp. Biochem. Physiol. 43a: 697-712

Cockcroft, A. C. (1988). The role of macrofauna in nitrogen recycling in a high energy surf zone. Ph. D. thesis, University of Port Elizabeth, South Africa

Cockcroft, A. C., Mclachlan, A. (1987). Nitrogen regeneration by the surf zone penaeid prawn Macropetasma africanus (Balss). Mar. Biol. 96: 343-348

Cockcroft, A. C., Webb, P., Wooldridge T (1988). Nitrogen regeneration by two surf-zone mysids, Mesopodsis slabberi and Gastrosaccus psammodytes. Mar Biol. 99: 75-82

Coleman, N., Trueman, E. R. (1971). The effect of aerial exposure on the activity of the mussels Mytilus edulis L. and Modiolus modiolus (L.) J. exp. mar Biol. Ecol. 7 295-304

Crenshaw, M. A. (1972). Inorganic composition of molluscan extrapallial fluid. Biol. Bull. mar. biol. Lab., Woods Hole 143: 506-512

De Voos, C. G. N., De Zwaan, A. (1978). The rates of oxygen consumption and ammonia excretion by Mytilus edulis after various periods of exposure to air Comp. Biochem. Physiol. 60: 343-347

De Zwaan, A., Van Marrewijk, W J. A. (1973). Anaerobic glucose degradation in the sea mussel Mytilus edulis L. Comp. Biochem. Physiol. 44b: 429-439

De Zwaan, A. Zandee, D. I. (1972). The utilization of glycogen and accumulation of some intermediates during anaerobiosis in Mytilus edulis L. Comp. Biochem. Physiol. 43b: $47-54$

Donn, T E., Clark, D. J., McLachlan, A., du Toit, P. (1986) Distribution and abundance of Donax serra Roding (Bivalvia: Donacidae) in relation to beach morphology. I. Semilunar migrations. J. exp. mar Biol. Ecol. 102: 121-131

Dye, A. H. (1979). The effect of acute and long-term temperature changes on the respiratory rate of two sand dwelling bivalves. Comp. Blochem. Physiol. 3b: 405-409

Hammen, C. S. (1968). Aminotransferase activities and amino acids excretion of bivalve molluscs and brachiopods Comp. Biochem. Physiol. 26: 697-705

Hammen, C. S. (1969). Metabolism of the oyster, Crassostrea virginica. Am. Zool. 9: 309-318

Hodgson, A. N., Fielden, L. J. (1984). The structure and distribution of peripheral ciliated receptors in the bivalve molluscs Donax serra and D. sordidus. J. mollusc. Stud. 50: $104-112$ 
Jordan, T E., Valiela, I. (1982). A nitrogen budget of the ribbed mussel, Geukensia demissa, and its significance in nitrogen flow in a New England salt marsh. Limnol. Oceanogr. 27. 75-90

Kautsky, N., Evans, S. (1987). Role of biodeposition by Mytilus edulis in the circulation of matter and nutrients in a Baltic coastal ecosystem. Mar Ecol. Prog. Ser 38: 201-212

Kautsky, N., Wallentinus, I. (1980). Nutrient release from a Baltic Mytilus - red algal community and its role in benthic and pelagic productivity. Ophelia, Suppl 1: 17-30

Kilburn, R., Rippey, E. (1982). The autobranch bivalves. In: Cadell, E. (ed.) Sea shells of Southern Africa. Macmillan, Johannesburg, p. 154-205

Kuenzler, E. J. (1961). Phosphorus budget of a mussel population. Limnol. Oceanogr. 6: 400-415

Lange, R. (1970). Isosmotic intracellular regulation and euryhalinity in marine bivalves. J. exp. mar. Biol. Ecol. 5: $170-179$

Lange, R. (1972). Some recent work on osmotic, ionic and volume regulations in marine animals. Oceanogr. mar. Biol. A. Rev. 10: 97-136

Lent, C. M. (1968). Air gaping by the ribbed mussel, Modiolus demissus (Dillwyn). Effects and adaptive significance. Biol. Bull mar biol. Lab., Woods Hole 134: 60-73

Lewin, J., Eckman, J. E., Ware, J. N. (1979). Blooms of surf zone diatoms along the coast of the Olympic Peninsula, Washington. XI. Regeneration of ammonia in the surf environment by the Pacific razor clam, Siliqua patula. Mar Biol. 52: 1-9

Lum, S. C., Hammen, C. S. (1964). Ammonia excretion of Lingula. Comp. Biochem. Physiol. 12: 185-190

McLachlan, A. (1979). Growth and production of Donax serra Hanley on an open sandy beach in Algoa Bay. S. Afr. J. Zool. 14: 61-66

McLachlan, A. (1980). Exposed sandy beaches as semi-closed ecosystem. Mar, environ. Res. 4: 59-63

McLachlan, A., Bate, G. (1984). Carbon budget for a high energy surf zone. Vie Milieu 34:67-77

This article was submitted to the editor
McLachlan, A., Hanekom, N. (1979). Aspects of the biology, ecology and seasonal flucturations in biochemical composition, of Donax serra in the East Cape. S. Afr J. Zool. 14: 183-193

McLachlan, A., Wooldridge, T., Dye, A. H. (1981). The ecology of sandy beaches of Southern Africa. S. Afr J. Zool. 16: 219-231

McLachlan, A., Wooldridge, T., van der Horst, G. (1979). Tidal movements of macrofauna on an exposed sandy beach in South Africa. J. Zool., Lond. 188: 433-442

McLachlan, A., Wooldridge, T., Schramm, T., Kuhn, M. (1980). Seasonal abundance, biomass and feeding of shorebirds on sandy beaches in the Eastern Cape, South Africa. Ostrich 51: 44-52

McLachlan, A., Young, N. (1982). Effects of low temperature on the burrowing rates of four sandy beach molluscs. J. exp. mar. Biol. Ecol. 65: 275-284

Moon, T W., Pritchard, A. W. (1970). Metabolic adaptions in vertically separated populations of Mytilus californianus Conrad. J. exp. mar. Biol. Ecol. 5: 35-46

Prosch, R., McLachlan, A. (1984). Regeneration of surf zone nutrients by the sand-mussel, Donax serra. J. exp. mar Biol. Ecol. 80: 221-233

Stokes, T. M., Awapara, J. (1968). Alanine and succinate as end-products of glucose degradation in the clam Rangia cuneata. Comp. Biochem. Physiol. 25: 883-892

Widdows, J., Bayne, B. L., Livingstone, D. R., Newell, R. I. E., Donkin, P. (1979). Physiological and biochemical responses of bivalve molluscs to exposure to air. Comp. Biochem. Physiol. 62a: 301-308

Widdows, J., Shick S. M. (1985). Physiological responses of Mytilus edulis and Cardium edule to aerial exposure. Mar Biol. 85: 217-232

Wijsman, T C. M. (1975). pH fluctuations in Mytilus edulis L. in relations to shell movements under aerobic and anaerobic conditions. In: Barnes, $H$. (ed.) Proc. 9th Europ. Mar. Biol. Symp. Aberdeen Univ. Press. Aberdeen, p. $139-149$

Manuscript first received: May 25, 1989

Revised version accepted: October 23, 1989 